\title{
Quantitative analysis of residual protein contamination of podiatry instruments reprocessed through local and central decontamination units
}

\author{
Gordon WG Smith ${ }^{1 \dagger}$, Frank Goldie², Steven Long ${ }^{3}$, David F Lappin ${ }^{1}$, Gordon Ramage ${ }^{1}$, Andrew J Smith ${ }^{1 * \dagger}$
}

\begin{abstract}
Background: The cleaning stage of the instrument decontamination process has come under increased scrutiny due to the increasing complexity of surgical instruments and the adverse affects of residual protein contamination on surgical instruments. Instruments used in the podiatry field have a complex surface topography and are exposed to a wide range of biological contamination. Currently, podiatry instruments are reprocessed locally within surgeries while national strategies are favouring a move toward reprocessing in central facilities. The aim of this study was to determine the efficacy of local and central reprocessing on podiatry instruments by measuring residual protein contamination of instruments reprocessed by both methods.
\end{abstract}

Methods: The residual protein of 189 instruments reprocessed centrally and 189 instruments reprocessed locally was determined using a fluorescent assay based on the reaction of proteins with o-phthaldialdehyde/sodium 2-mercaptoethanesulfonate.

Results: Residual protein was detected on $72 \%(n=136)$ of instruments reprocessed centrally and $90 \%(n=170)$ of instruments reprocessed locally. Significantly less protein $(p<0.001)$ was recovered from instruments reprocessed centrally (median $20.62 \mu \mathrm{g}$, range 0 - $5705 \mu \mathrm{g}$ ) than local reprocessing (median $111.9 \mu \mathrm{g}$, range 0 - $6344 \mu \mathrm{g}$ ).

Conclusions: Overall, the results show the superiority of central reprocessing for complex podiatry instruments when protein contamination is considered, though no significant difference was found in residual protein between local decontamination unit and central decontamination unit processes for Blacks files. Further research is needed to undertake qualitative identification of protein contamination to identify any cross contamination risks and a standard for acceptable residual protein contamination applicable to different instruments and specialities should be considered as a matter of urgency.

\section{Background}

The decontamination processes for medical instruments are under constant review as new challenges to instrument reprocessing emerge due to the increasing complexity of instruments and the emergence of variant Creutzfeldt Jackob disease (vCJD) which demonstrates reduced susceptibility to the common microbial

\footnotetext{
* Correspondence: andrew.smith@glasgow.ac.uk

† Contributed equally

'Institute of Infection, Immunity and Inflammation, Glasgow Dental School, College of Medicine, Veterinary and Life Sciences University of Glasgow, Glasgow, G2 3JZ, UK

Full list of author information is available at the end of the article
}

inactivation processes [1]. Investigations into the biological properties of prion protein have highlighted the importance of the cleaning phase to remove protein and debris [2,3]. Moreover, the presence of residual protein on surgical instruments has been shown to increase the dissolution of metal ions, therefore increasing the rate of corrosion of certain instrument stainless steel [4]. In addition, residual protein may promote the adhesion of bacteria through specific adhesion receptors, such as fibronectin binding protein found in Staphylococcus aureus [5]. Protein can also inhibit sterilization processes if not removed during instrument cleaning [6]. 
Currently, the majority of podiatry instrument reprocessing is undertaken in local decontamination units (LDU). However, national strategies have favoured a predilection towards the centralisation of sterile services and the reprocessing of instruments at a central decontamination unit (CDU) [7]. CDU's offer the advantages of validated modern equipment, specialist knowledge, and shifts the legal responsibility of instrument reprocessing from the practitioner. Reprocessing in the LDU offers advantages with a faster instrument turnaround time and lower instrument inventory.

It is therefore important to determine the efficiency of the CDU process compared to current LDU processes at removing protein contamination to partly justify the change in strategy.

The aim of this study was to compare the efficacy of LDU and CDU reprocessing of podiatry instruments by a quantitative assessment of residual protein following routine use of the instruments.

\section{Methods}

Pear burs $(n=126)$, Blacks files $(n=126)$ and Diamond Deb files $(n=126)$ manufactured by Timesco instruments UK were collected for the study after single use and randomly allocated into two groups for reprocessing. The first group was subjected to routine cleaning and sterilization by LDU's (Table 1 ) and the second group were subjected to reprocessing by the CDU at Cowlairs SSD Glasgow (Table 2). New, unused instruments representative of each type were also acquired from the manufacturers to serve as negative controls.

Individual Blacks and Diamond Deb files were placed in a sterile plastic bag (Seward, UK), whilst each Pear bur was added to a sterile $25 \mathrm{ml}$ Universal tube (Corning, UK). Residual protein was desorbed from each instrument by immersion in a standardised volume of $1 \% \mathrm{v} / \mathrm{v}$ sodium dodecyl sulphate (SDS) (Sigma UK), and for Pear burs only the working end was immersed. Each instrument was subjected to sonication at $35 \mathrm{kHz}$ for $30 \mathrm{~min}$ in an ultrasonic bath (Thermofisher Fisherbrand ${ }^{\circledR} 11021$ sonic bath (Fisher Scientific, Loughborough UK) [8]. The protein desorbed from each instrument was subsequently quantified using a modification of the o-phthaldialdehyde (OPA)/sodium-2-mercaptoethanesulfonate assay, has a lower limit of detection of $5 \mu \mathrm{g} / \mathrm{ml}$ (See additional file 1). Briefly, the reagent was prepared by dissolving phthaldialdehyde (Sigma, Dorset UK) in methanol (BDH Laboratory supplies, Leicester, UK) to a produce a $300 \mathrm{mM}$ solution. This was then added at a concentration of 1:50 into 1.2 M sodium 2-mercaptoethanesulfonate prepared in sodium tetraborate (100 mM [pH 9.2]). A $20 \mu \mathrm{l}$ desorbed sample was added to a black Costar ${ }^{\text {in }}$ flat bottomed 96 well plate (Sigma, Dorset UK M9936) in combination with $300 \mu \mathrm{l}$ of OPA reagent, as previously described by Zhu and colleagues [9]. The samples were incubated for $3 \mathrm{~min}$ at ambient room temperature before being measured using an Omega FluoStar plate reader (BMG Labtech, Aylesbury UK) at excitation wavelength $355 \mathrm{~nm}$ and emission wavelength $460 \mathrm{~nm}$.

Data was analysed using SPSS (SPSS. Inc., Chcago, IL, USA) and the distribution of the data determined using the Kolmogorov-Smirnov test. The resultant non-parametric data was then compared using the Mann Whitney $\mathrm{U}$ test to analyse the differences between instruments reprocessed using the LDU and CDU, and to compare and analyse differences between each of the different instrument groups. The significance was determined by a 2-tailed Monte Carlo estimation.

\section{Results}

A total of 58/63 Pear burs, 48/63 Blacks files and 31/63 Diamond Deb files reprocessed by CDU contained greater than $5 \mu \mathrm{g} /$ instrument of detectable protein. Protein was also detected in 62/63 Pear burs, 53/63 Black files, and 56/63 Diamond Deb files reprocessed by LDU (Figure 1). Instruments reprocessed by the CDU (median $21 \mu \mathrm{g} /$ instrument range $0-5705 \mu \mathrm{g} /$ instrument) had significantly less residual protein than instruments reprocessed by the LDU (median $117 \mu \mathrm{g} /$ instrument range $0-6344 \mu \mathrm{g} /$ instrument) when all three instruments were grouped $(\mathrm{p}<0.001)$.

For individual instruments, the median quantity of protein detected on Pear burs (Figure 2) reprocessed by CDU was significantly lower (median $11 \mu \mathrm{g} /$ instrument

Table 1 Details of Podiatry LDU decontamination processes

\begin{tabular}{ll}
\hline Cleaning process & Hygena Ultrawave ultrasonic bath \\
\hline Equipment & Sonozyme-solution changed twice daily \\
\hline Detergent & 6 mins $/ 35^{\circ} \mathrm{C}$ \\
\hline Cleaning time/temperature & Tests and documentation supplied by manufacturer (Ultrawave) \\
\hline Validated & \\
\hline Sterilization Process & Little sister 3 Type N (Non vacuum) \\
\hline Equipment & Steam sterilization \\
\hline Method &
\end{tabular}


Table 2 Details of Cowlairs CDU decontamination processes

\begin{tabular}{ll}
\hline Cleaning Process & \\
\hline Equipment & Getinge Automated Washer Disinfector \\
\hline Detergent & Dr Weigert Neodisher Mediclean Fort \\
\hline Cleaning time/temperature & Pre rinse -4 min $38 \mathrm{sec} / \mathrm{Start} 31^{\circ} \mathrm{C}$ End $34.9^{\circ} \mathrm{C}$ \\
& Main wash -7 mins $20 \mathrm{sec} / \mathrm{Start} 60.5^{\circ} \mathrm{C}, \mathrm{End} 62.8^{\circ} \mathrm{C}$ \\
& Hot water rinse $-2 \mathrm{mins} / \mathrm{Start} 91.4^{\circ} \mathrm{C}, \mathrm{End} 92.6^{\circ} \mathrm{C}$ \\
& Disinfection $-1 \mathrm{~min} 30 \mathrm{secs} 37$ \\
\hline Validated & Drying -22 min $22 \mathrm{secs} / \mathrm{Start} 82.3^{\circ} \mathrm{C}$, End $87.2^{\circ} \mathrm{C}$ \\
\hline Sterilization Process & Washer disinfector by trust engineer to protocols defined in SHTM2030 \\
\hline Equipment & \\
\hline Method & Getinge Type B (Vacuum sterilizer) \\
\hline
\end{tabular}

range $0-161.7 \mu \mathrm{g} /$ instrument) than those by LDU (median $77 \mu \mathrm{g}$ /instrument, range $0-1403 \mu \mathrm{g}$ /instrument $\mathrm{p}<$ $0.001)$. The median quantity of protein detected on Blacks files (Figure 3) reprocessed by CDU (median $64.52 \mu \mathrm{g} /$ instrument, range $0-1113 \mu \mathrm{g} /$ instrument) exhibited no significant difference compared to protein detected on Blacks files by LDU (median $50.81 \mu \mathrm{g}$ / instrument, range 0-633.5/instrument). The median quantity of protein detected on Diamond Deb files (Figure 4) reprocessed by CDU was significantly lower $(0 \mu \mathrm{g}$ range $0-5705 \mu \mathrm{g})$ than Diamond deb files reprocessed by LDU (median $711.8 \mu \mathrm{g}$, range 0 - 6344) ( $\mathrm{p}<$ $0.05)$. However, residual protein was still detected from these instruments, as the mean of these was $512 \mu \mathrm{g}$ for

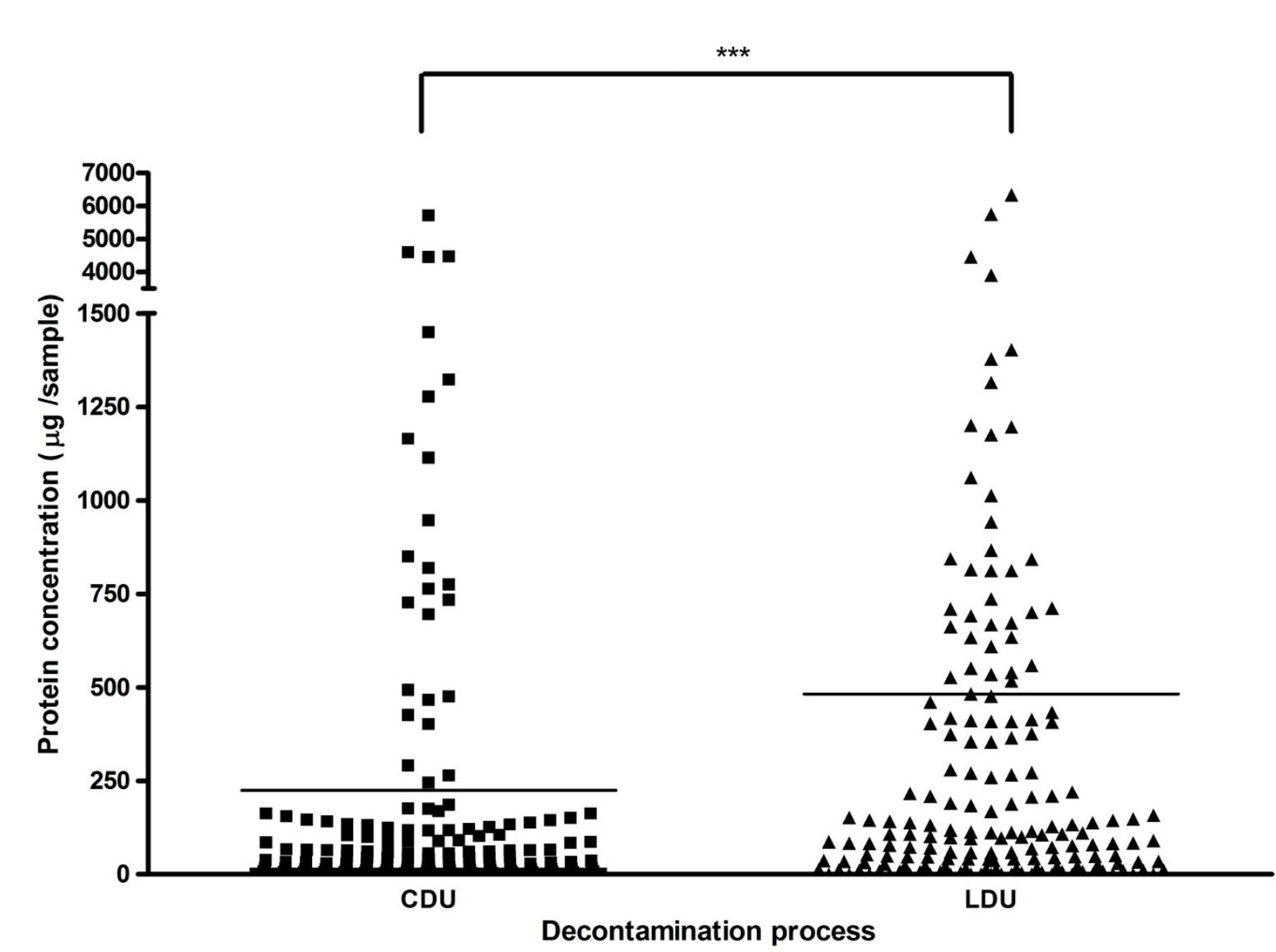

Figure 1 Residual protein isolated from all instruments after reprocessing by both methods $(* * *=\mathrm{P}<0.001)$. 


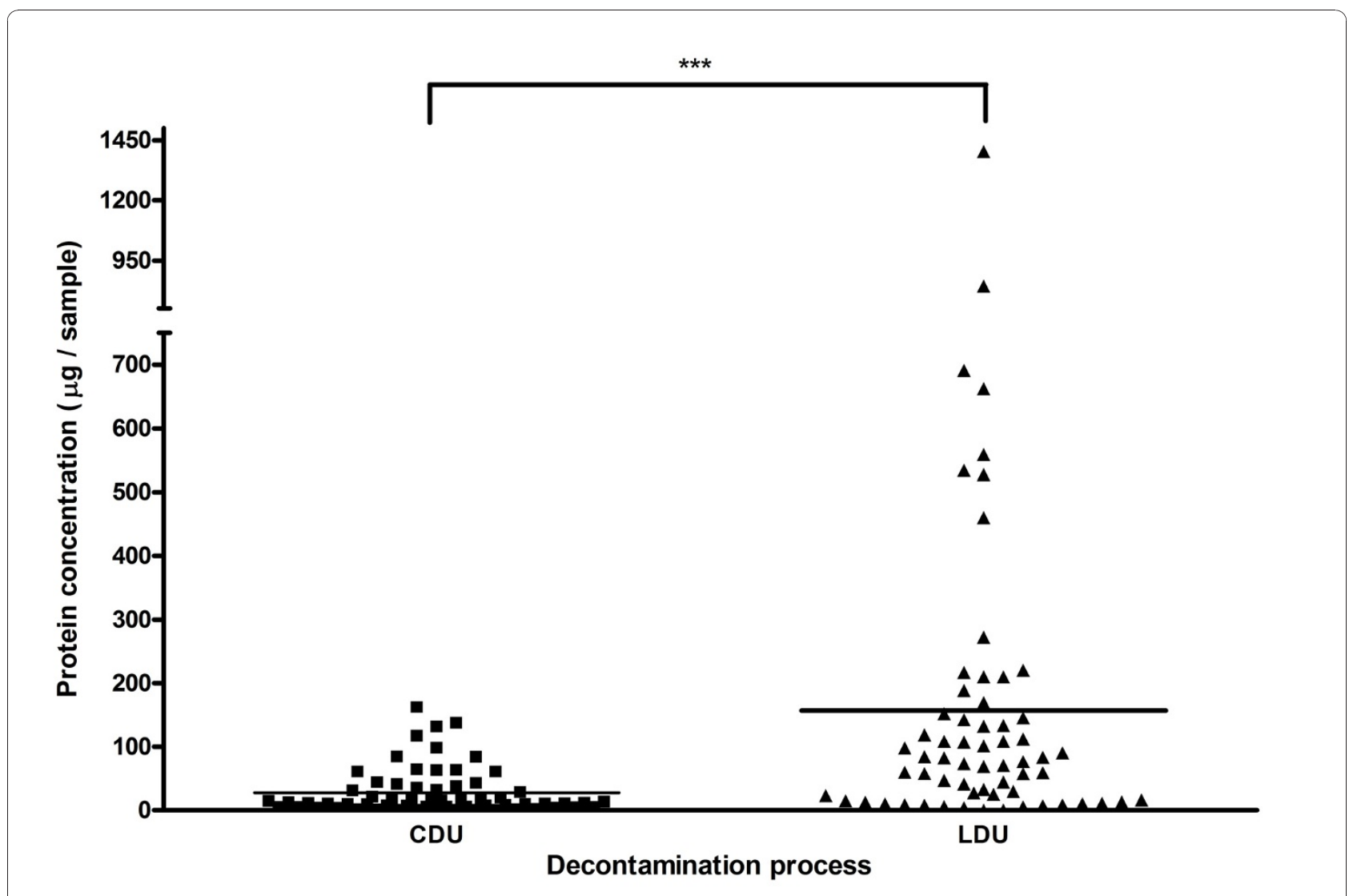

Figure 2 Total residual protein recovered from individual Pear burs reprocessed by both methods $(* * * P<0.001)$.

CDU reprocessing compared to $1159 \mu \mathrm{g}$ for LDU reprocessing, indicating that a small proportion of CDU samples contained elevated levels of residual protein.

\section{Discussion}

The cleaning stage of the medical instrument decontamination process has become increasingly important due to the emergence of (vCJD) and from the reported inhibition of the sterilization process caused by residual protein contamination [6]. Whilst there is an increasing trend for instruments to be reprocessed in centralised facilities, the majority of podiatry instruments are reprocessed locally. Concerns have been raised whether reprocessing in the LDU is less effective than the CDU for the decontamination of medical instrumentation [10].

This study was the first to directly compare the efficacy of CDU and LDU cleaning processes using podiatry instruments which were contaminated following routine use. When all podiatry instruments were grouped, the CDU instruments were found to contain significantly less residual protein than an identically sized group of instruments reprocessed by the LDU. The reason for the difference in cleaning efficacies between the CDU and the LDU are multifactorial and include a more robust validation process for the automated washer disinfectors (AWD) in use at the CDU. Other factors include an increased cleaning process time in the CDU (11 minCDU compared to $6 \mathrm{~min}$ - LDU), different cleaning chemistries used, the differences in form of energy used in cleaning processes, and different temperatures used during the wash stage.

Similar patterns of cleaning efficacy were observed within each group of instruments with the exception of Blacks files, which may be due to the smaller ridged surface area compared to the more complex surface topography associated with the other instruments. This characteristic has been associated with increased retention of contamination by surface analysis of endodontic files which also have a ridged surface topography [11].

No single standard yet exists for "acceptable" protein levels on reprocessed instruments. The BS EN ISO15883-1: 2006 for validation of washer disinfectors defines an acceptable level as below the detection limit of one of three protein assays which are stated as $2 \mathrm{mg} / \mathrm{m}^{2}$ for the Ninhydrin assay, $30-50 \mu \mathrm{g}$ for the bicinchoninic acid assay, and $0.003 \mu \mathrm{mol}$ of OPA sensitive amino groups for the OPA assay [12]. Work undertaken by Lipscomb and colleagues (2006) also determined the 


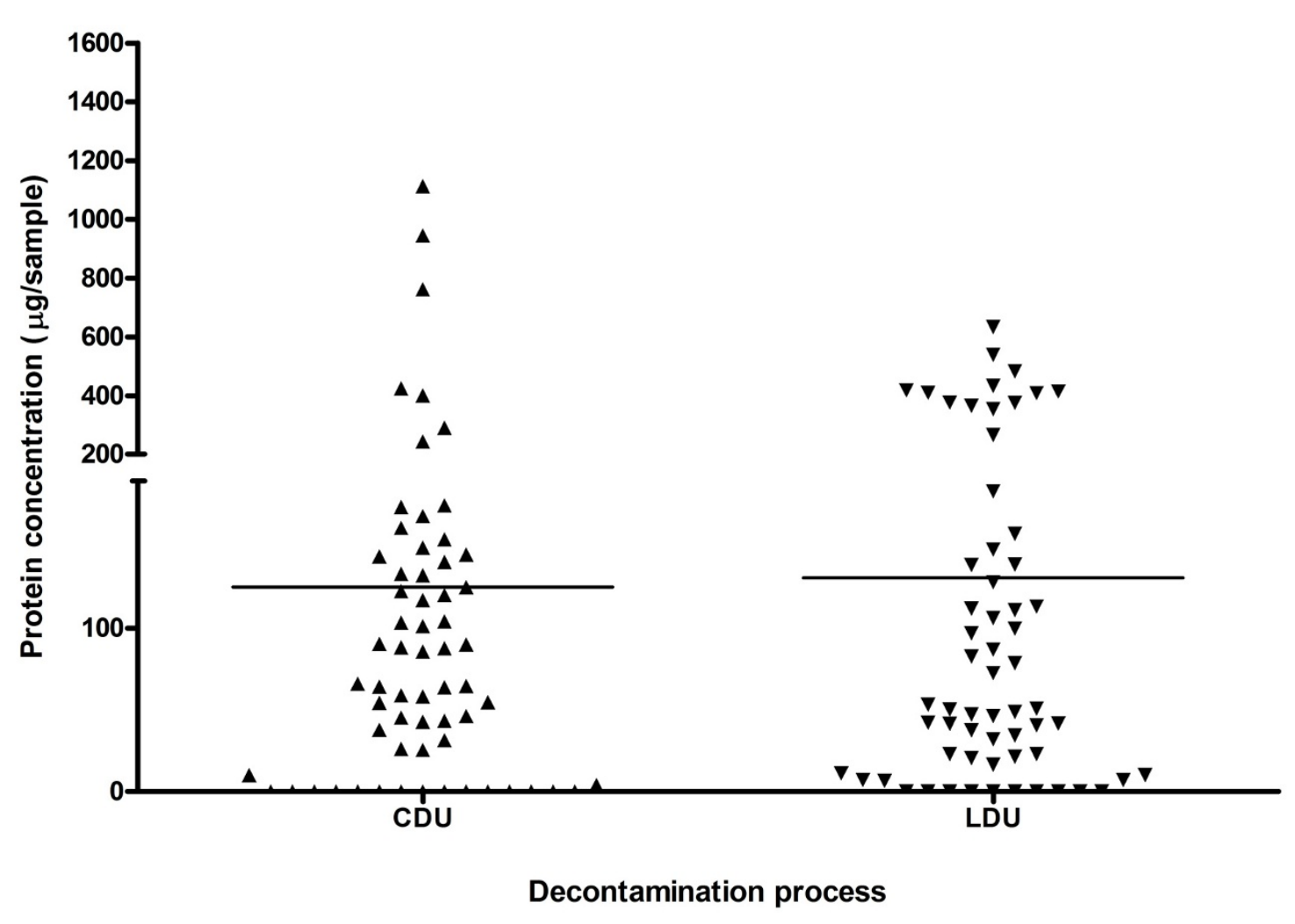

Figure 3 Total residual protein recovered from individual Blacks files reprocessed by both methods.

threshold of sensitivity for similar reagents to be equivalent to $9.25 \mu \mathrm{g} / 10 \mathrm{~mm}^{2}$ for Ninhydrin and $6.7 \mu \mathrm{g} / 10 \mathrm{~mm}^{2}$ for the Biuret test [13]. Our group have determined a lower limit of detection for the OPA assay to be $5 \mu \mathrm{g} / \mathrm{ml}$ (see supplementary figure). If this was to be regarded as a threshold for cleanliness for reprocessed instruments, a total of 68/189 instruments reprocessed by CDU and 19/ 189 instruments reprocessed by the LDU would be deemed to be clean. The number of clean instruments may drop considerably if more sensitive analytical procedure were employed.

The data reported herein highlights the superiority of the CDU process in terms of cleaning efficacy at reprocessing more complex instruments. Previous studies have focused on the efficacy of CDU reprocessing by assaying a range of surgical instruments containing residual protein that was detected after reprocessing $[8,14]$. The protein content of different surgical instruments, including metzenbaum scissors and forceps, ranged from 163 to $756 \mu \mathrm{g}$, which is similar to that reported herein $[14,15]$. Similarly, a study on reprocessed dental endodontic files, which have a complex surface topography, showed a range of protein from 0.2 to $63.2 \mu \mathrm{g}$, similar to those levels observed on the Pear burs [8].
In order to improve validation of instrument reprocessing from visual inspection and published standards, techniques with greater quantitative sensitivity have emerged. Examples include a fluorescent microscopy technique involving visualisation of protein by SYPRO ruby staining capable of detecting $85 \mathrm{pg}$ of protein on a surface area of $1 \mathrm{~mm}^{2}$ which is significantly lower than the sensitivity of $5 \mu \mathrm{g} /$ instrument reported in this study [10]. A standard for cleanliness when considering protein contamination should be dependent on the procedures undertaken by the instrument. The total protein recovered from the podiatry instruments would be equivalent to a large number of prion infectious units [13].

\section{Conclusions}

Residual protein has been recovered from podiatry instruments reprocessed by the CDU and the LDU. This study has shown that overall, the CDU is superior to the LDU with respect to podiatry instrument reprocessing and that the level of complexity of the instrument may dictate the level of reprocessing for example the adoption of a single use policy or enhanced cleaning validation processes for certain instrument designs. Further studies are required to evaluate the reprocessing of a 


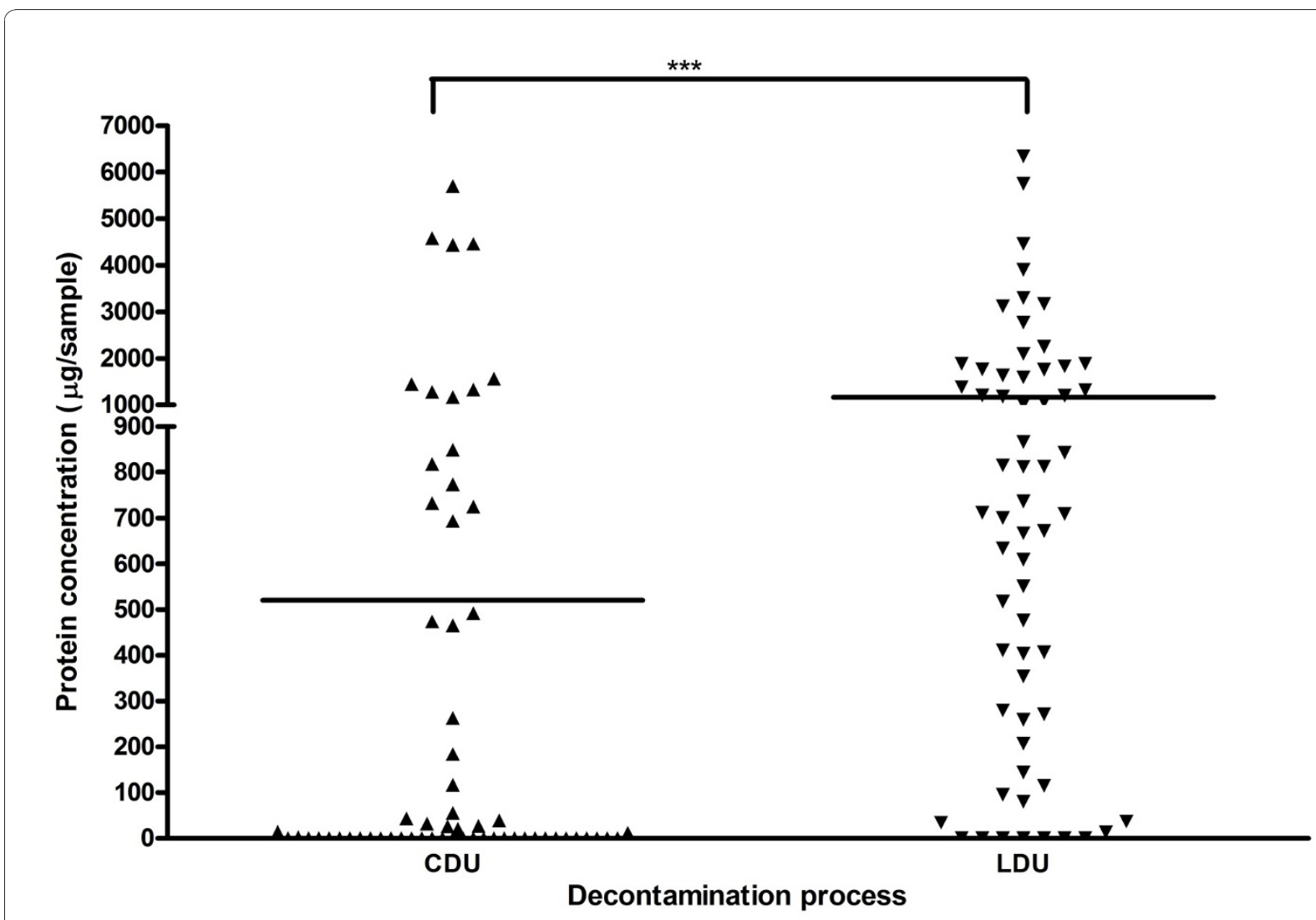

Figure 4 Total residual protein recovered from individual Diamond deb files reprocessed by both methods $(* * *=P<0.001$ ).

range of medical instruments using similar methodologies to those employed within this study, which will help validate these data. Moreover, understanding which proteins are associated with instruments is of critical importance, as this will have implications with regards to safety and risk assessment.

\section{Additional material}

Additional file 1: Method validation. Details of the methods and the results of validation experiments for the protein detection and protein extraction methods used in this study.

\section{Acknowledgements}

The authors would like to acknowledge the contribution of Andrea Sherrif who advised on the study design. GWGS also acknowledges W \& H Dentalwerk for providing PhD funding.

\section{Author details}

${ }^{1}$ Institute of Infection, Immunity and Inflammation, Glasgow Dental School, College of Medicine, Veterinary and Life Sciences University of Glasgow, Glasgow, G2 3JZ, UK. ${ }^{2}$ Central Decontamination Unit Cowlairs Industrial Estate 24 Finlas Street, Glasgow, G22 5DT, UK. ${ }^{3}$ Podiatry Lead (North Acute) Department of Podiatry, Glasgow Royal Infirmary, Alexandra Parade, Glasgow G31 2ER, UK

\section{Authors' contributions}

GWGS carried out the processing and the subsequent protein analysis of all the instruments and for the overall study design and for the drafting of the manuscript. FG and SL were responsible funding of the chemicals used in the study, the sourcing of the instruments from community podiatry and the CDU and for helping in drafting the manuscript. DL carried out the statistical analysis and aided in study design. GR and AJS were responsible for the overall design of the study and aided in the final drafting of the manuscript. All authors have read and approved the final manuscript.

\section{Competing interests}

The authors declare that they have no competing interests.

Received: 19 October 2010 Accepted: 10 January 2011

Published: 10 January 2011

\section{References}

1. Bernoulli C, Siegfried J, Baumgartner G, Regli F, Rabinowicz T, Gajdusek DC, Gibbs CJ Jr: Danger of accidental person-to-person transmission of Creutzfeldt-Jakob disease by surgery. Lancet 1977 1:478-479.

2. Taylor DM: Inactivation of BSE agent. Dev Biol Stand 1991, 75:97-102.

3. Herve R, Secker TJ, Keevil CW: Current risk of iatrogenic Creutzfeld-Jakob disease in the UK: efficacy of available cleaning chemistries and reusability of neurosurgical instruments. J Hosp Infect 75:309-313.

4. Kocijan A, Milosev I, Pihlar B: The influence of complexing agent and proteins on the corrosion of stainless steels and their metal components. J Mater Sci Mater Med 2003, 14:69-77.

5. Piroth L, Que YA, Widmer E, Panchaud A, Piu S, Entenza JM, Moreillon P: The fibrinogen- and fibronectin-binding domains of Staphylococcus 
aureus fibronectin-binding protein A synergistically promote endothelial invasion and experimental endocarditis. Infect Immun 2008, 76:3824-3831.

6. Amaha M, Sakaguchi Kl: Effects of carbohydrates, proteins, and bacterial cells in the heating media on the heat resistance of Clostridium sporogenes. J Bacteriol 1954, 68:338-345.

7. The Glennie Framework: The decontamination of surgical instruments and other medical devices. Report of a Scottish executive health department working group. February 2001.

8. Smith A, Letters S, Lange A, Perrett D, McHugh S, Bagg J: Residual protein levels on reprocessed dental instruments. J Hosp Infect 2005, 61:237-241.

9. Zhu D, Saul A, Huang S, Martin LB, Miller LH, Rausch KM: Use of ophthalaldehyde assay to determine protein contents of Alhydrogelbased vaccines. Vaccine 2009, 27:6054-6059.

10. Lipscomb IP, Sihota AK, Keevil CW: Comparative study of surgical instruments from sterile-service departments for presence of residual gram-negative endotoxin and proteinaceous deposits. J Clin Microbiol 2006, 44:3728-3733.

11. Smith A, Dickson M, Aitken J, Bagg J: Contaminated dental instruments. J Hosp Infect 2002, 51:233-235.

12. Mehta JS, Osborne R: CJD and intraocular surgery. Eye 2004, 18:1272-1273.

13. Lipscomb IP, Pinchin HE, Collin R, Harris K, Keevil CW: The sensitivity of approved Ninhydrin and Biuret tests in the assessment of protein contamination on surgical steel as an aid to prevent iatrogenic prion transmission. J Hosp Infect 2006, 64:288-292.

14. Murdoch H, Taylor D, Dickinson J, Walker JT, Perrett D, Raven ND, Sutton JM: Surface decontamination of surgical instruments: an ongoing dilemma. J Hosp Infect 2006, 63:432-438

15. Baxter RL, Baxter HC, Campbell GA, Grant K, Jones A, Richardson P, Whittaker G: Quantitative analysis of residual protein contamination on reprocessed surgical instruments. J Hosp Infect 2006, 63:439-444.

doi:10.1186/1757-1146-4-2

Cite this article as: Smith et al:: Quantitative analysis of residual protein contamination of podiatry instruments reprocessed through local and central decontamination units. Journal of Foot and Ankle Research 2011 4:2.

\section{Submit your next manuscript to BioMed Central and take full advantage of:}

- Convenient online submission

- Thorough peer review

- No space constraints or color figure charges

- Immediate publication on acceptance

- Inclusion in PubMed, CAS, Scopus and Google Scholar

- Research which is freely available for redistribution

Submit your manuscript at www.biomedcentral.com/submit 